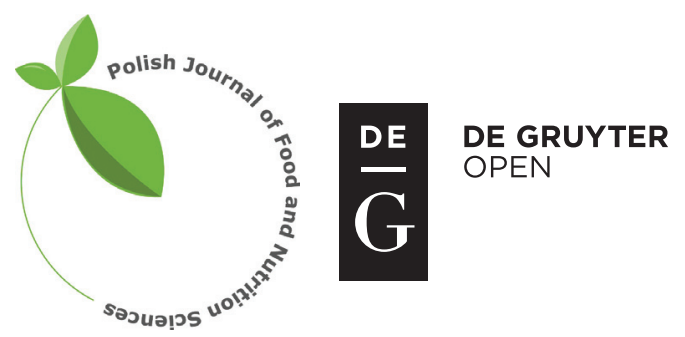

Pol. J. Food Nutr. Sci., 2016, Vol. 66, No. 4, pp. 311-319

DOI: $10.1515 /$ pjfns-2015-0058 http://journal.pan.olsztyn.pl

Original article

Section: Food Quality and Functionality

\title{
Comparison of Physicochemical Properties, Fatty Acid Composition and Mineral Contents in Common Carp (Cyprinus carpio L.) Fillet and the Native Traditional Product Carp Ham
}

\author{
Piotr Skatecki ${ }^{1}$, Mariusz Florek ${ }^{1}$, Anna Pyć2, Agnieszka Kaliniak ${ }^{1}$, Agnieszka Staszowska ${ }^{1}$

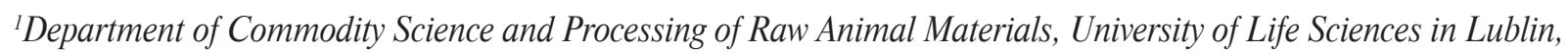 \\ Akademicka 13, 20-950 Lublin, Poland \\ ${ }^{2}$ Fish Farm 'Pstrag Pustelnia', Trzebiesza 69, 24-320 Poniatowa, Poland
}

Key words: common carp, traditional manufacturing, Carp Ham, quality

Based on the analysis of the proximate composition, mineral contents and fatty acid profiles, the objective of this study was to evaluate the nutritional value of the traditional product Carp Ham produced from common carp raw fillets. Significant differences were found in the proximate composition and mineral contents between the raw fillets and the final product. The contents of protein, fat and ash in $100 \mathrm{~g}$ of the traditional product $(21.94,8.63$ and $6.58 \mathrm{~g})$ were higher $(\mathrm{P}<0.01)$ than in fillets $(19.28,1.53$ and $1.22 \mathrm{~g})$, with an exception of the moisture content $(63.60 \mathrm{vs.} 77.79 \mathrm{~g})$. Significantly higher energetic value showed Carp Ham $(692 \mathrm{~kJ} / 100 \mathrm{~g})$ as compared to fillets $(384 \mathrm{~kJ} / 100 \mathrm{~g})$. Carp fillet and Ham showed high values of the index of nutritive quality (INQ) for protein (8.43 and 5.44). Processing had a significant influence $(\mathrm{P}<0.05)$ on the decrease of $\mathrm{K}, \mathrm{Mg}$ and $\mathrm{Ca}$ contents in Carp Ham $(3107.8,236.2$ and $107.7 \mathrm{mg} / \mathrm{kg}$ ), and the increase of $\mathrm{Fe}, \mathrm{Zn}, \mathrm{Mn}$ and $\mathrm{Cu}$ concentrations $(2.10,3.10,0.50 \mathrm{and} 0.16 \mathrm{mg} / \mathrm{kg})$. Among the fatty acids, the only significant differences were stated for C20:1n-9 (2.22 vs. 1.76\%) and C22:6n-3 (1.34 vs. 0.83\%), with the higher values determined for fillets. The traditional product, Carp Ham, preserved positive nutritional features, which were better highlighted by the fatty acid composition, health-related indices and oxidative stability. The study indicated that the traditional manufacturing method retains the most part of the nutritional constituents present in the carp fillets.

\section{INTRODUCTION}

Fish and fish products are recommended as part of a healthy and balanced diet, and their consumption has long been associated with several health outcomes. Fish provides a variety of nutrients, including protein and long-chain omega-3 polyunsaturated fatty acids (n-3 PUFAs), as well as micronutrients, including vitamins (e.g. A, D and B) and minerals (e.g. iodine, selenium) [Weichselbaum et al., 2012].

Common carp is one of the most widely cultured freshwater species all over the world, with a total aquaculture production of 3.6 million tonnes [FAO, 2012]. This resulted from its fast growth rate, easy cultivation, as well as high ratio of feed efficiency, and high nutritive value [Tokur et al., 2006]. The species was introduced into Europe from Asia. The history of the presence of carp in Polish waters and its farming in traditional earthen ponds (in two- or three-year cycles) reaches as far back as the $12^{\text {th }}$ century. In 2012, the overall production of carp in Poland amounted to 17,700 tonnes, that was $49 \%$ of the total production of fish from aquaculture [Hryszko, 2013].

Fish smoking is relevant in the fisheries in that it prolongs the fish's shelf life, enhances the fish's sensory proper-

\footnotetext{
* Corresponding Author: Tel: +48 81 4456621; Fax: +48 81 4456784;

E-mail: mariusz.florek@up.lublin.pl (M. Florek)
}

ties and increases the utilisation of the fish. The traditional cold smoking of fish includes salting (with or without sugar), drying and smoking at low temperatures. In Poland, the production of smoked fish in 2012 exceeded 85,000 tonnes, accounting for approximately $20 \%$ of the total production structure. The consumption of fish, fish products and seafood in 2012 amounted to $11.7 \mathrm{~kg}$ per capita. Within the consumption structure, the proportion of smoked fish was $11.9 \%$ [Hryszko, 2013].

Carp Ham is produced at the 'Pstrąg Pustelnia' (Trout Hermitage) Fish Farm (Lubelskie Voivodeship) in Poland. The Lublin region is the second-largest carp farming area in Poland. The conditions on the farm are convenient for a semi-intensive carp breeding system. Fish Farm was established in 1994, however, the historical data of carp production in this area reached back to the $18^{\text {th }}$ century. Traditional product Carp Ham is defined as fillets of carp that have been smoked in accordance with the traditional local method (without chemicals or preservatives). Regular monitoring of the smoking process by skilled smokers is carried out to ensure that the product is smoked evenly, moving and removing hams when necessary. Carp Ham is usually smoked on request and available on the farm year-round. The maintenance of freshness and high quality of the product without packaging ensure its distribution within two days following processing. 
In Poland, each region has its own long culinary tradition and unique products from carp. Some carps from specific locations are especially valued, as reflected in their registration as a traditional specialty, e.g. Zator carp is also listed as a product with Protected Designation of Origin (PDO) [EC, 2011]. However, most of carp native products have been registered based on the regulations by the Polish Ministry of Agriculture and Rural Development [MARD, 2014].

Many reports have focused on alternative products from carp mince, such as fish burgers, fingers or balls, as well as frankfurters and other sausages [Gelman \& Benjamin, 1989; Tokur et al., 2006; Yanar \& Fenercioglu, 1998].

This study was designed to compare the physicochemical properties, fatty acid composition and mineral contents of a native traditional product, Carp Ham, which is prepared from fresh fillets of common carp (Cyprinus carpio).

\section{MATERIALS AND METHODS}

\section{Raw material}

From the selected batch that was used in the production process of the Carp Ham, a representative sample of 12 fish was taken in June 2013. For non-stressful slaughtering, the fish were removed from the water, electrically stunned and decapitated according to a processing plant's procedure by a highly-skilled employee. Fish used in the manufacturing of Carp Hams were evaluated by measuring total weight $( \pm 0.1 \mathrm{~g})$, as well as the total and body length $( \pm 1 \mathrm{~mm})$, maximal and minimal height $( \pm 1 \mathrm{~mm})$, body width $( \pm 1 \mathrm{~mm})$, weight $( \pm 0.1 \mathrm{~g})$ and share $(\%)$ of skeleton, as well as weight and $( \pm 0.1 \mathrm{~g})$ and share $(\%)$ of fillet and skin. The measurements of the intrinsic properties and chemical compounds determinations of fresh fillets $(n=12)$ were performed on the first day of production of Carp Ham. Detailed characterisation of subsequent stages of Carp Ham production is shown in Table 1. Analyses of the final products $(n=6)$ were performed after manufacturing on the fifth production day. Fish and Carp Hams were placed in cooling containers and transported within $2 \mathrm{~h}$ to the laboratory. The appearance of Carp Ham was assessed, and the following metric measurements were recorded: total weight $(\mathrm{g})$, net weight $(\mathrm{g})$, length $(\mathrm{cm})$, diameter $(\mathrm{cm})$ and circumference $(\mathrm{cm})$.
TABLE 1. Production method of Carp Ham.

\begin{tabular}{|c|c|c|}
\hline Stage & Operations & Specification \\
\hline 1 & Raw materials & $\begin{array}{c}\text { Fresh carps from Pstrąg } \\
\text { Pustelnia farm }\end{array}$ \\
\hline 2 & Descaling and eviscerating & Removing scales and viscera \\
\hline 3 & Deboning & $\begin{array}{l}\text { Special way of cutting } \\
\text { eliminates backbones } \\
\text { and fish bones }\end{array}$ \\
\hline 4 & Soaking in brine & $\begin{array}{l}\text { Clean fillets immersed } \\
\text { in brine solution } 10 \% \\
(\mathrm{w} / \mathrm{v}) \text { for up } 24 \mathrm{~h} \text { at } 4^{\circ} \mathrm{C}\end{array}$ \\
\hline 5 & Drying & Drying at $15^{\circ} \mathrm{C}$ for $45 \mathrm{~min}$ \\
\hline 6 & Forming & $\begin{array}{l}\text { The fillets are rolled } \\
\text { by hand, and a small } \\
\text { ham body is formed, } \\
\text { and then placed in a net }\end{array}$ \\
\hline 7 & Smoking & $\begin{array}{l}\text { Maturation - smoking } \\
\text { is carried out using cold } \\
\text { smoke (at } 40^{\circ} \mathrm{C} \text { ) of alder } \\
\text { wood and lasts from } 72 \mathrm{~h}\end{array}$ \\
\hline 8 & Cooling & Cooling to $20^{\circ} \mathrm{C}$ for $2 \mathrm{~h}$ \\
\hline 9 & Storage & $\begin{array}{l}\text { Storage at } 4^{\circ} \mathrm{C} \text { until sold } \\
\text { to the consumers }\end{array}$ \\
\hline
\end{tabular}

\section{Fillet and Carp Ham measurements}

\section{Intrinsic properties}

After the initial fish processing, the intrinsic qualities of the dorsal fillet were analysed. The $\mathrm{pH}$ value directly in the middle of the product was measured using a pIONneer 65 Meter (Radiometer Analytical, Villeurbanne, CEDEXFrance)

The colour of the fillets and Carp Hams (after division into halves, Figure 1) was measured by a Minolta CR-310 Chroma Meter (Minolta Camera Co. Ltd., Osaka, Japan), using D65 as the standard light source, wide area $/ 0^{\circ}$ angle illumination, and $50 \mathrm{~mm}$ diameter of measure aperture. The absolute results (from two replications) are presented as CIE L*a*b* values [CIE, 2004], were $L^{*}$ is lightness $\left(L^{*}=100\right.$ for white and 0 for black), $\mathrm{a}^{*}$ is the redness/greenness axis (positive/ negative $a^{*}$, respectively), and $b^{*}$ is the yellowness/blueness axis (positive/negative $\mathrm{b}^{*}$, respectively). Chroma value $\left(\mathrm{C}^{*}\right)$
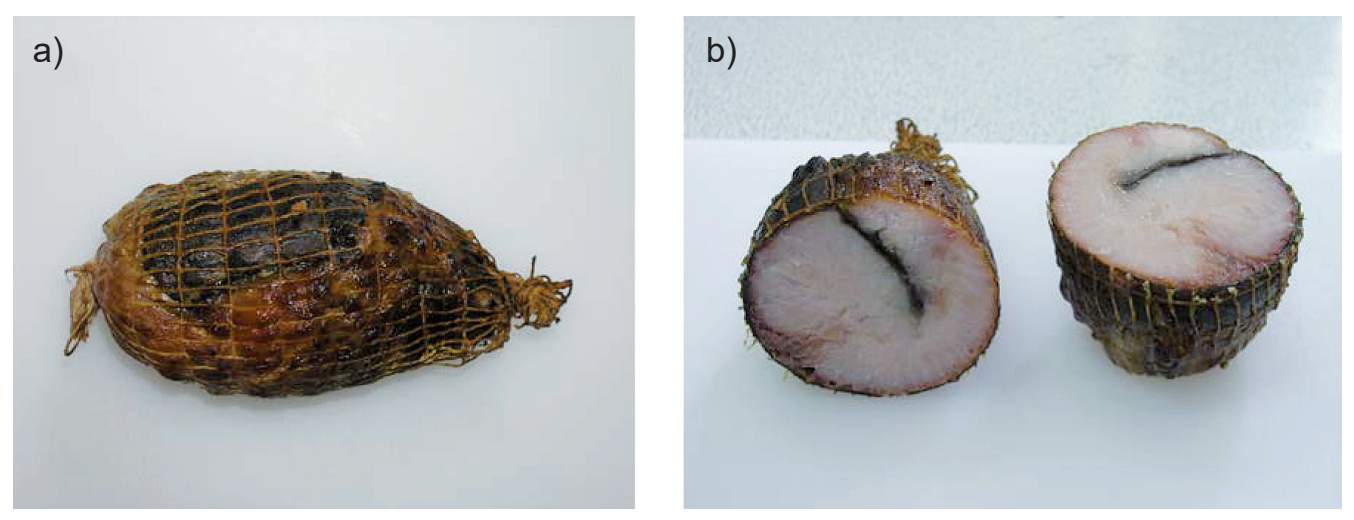

FIGURE 1. Carp Ham from Pustelnia Fish Farm: a) whole, b) cross-section. 
is a measure of saturation and represents the distance from the neutral axis. Hue value $\left(h^{\circ}\right)$ is represented as an angle ranging from 0 to $360^{\circ}$. The colour difference $(\Delta \mathrm{E})$ between raw fillet and ready product denotes the square root of $\left(\Delta \mathrm{L}^{2}\right.$ $\left.+\Delta \mathrm{a}^{2}+\Delta \mathrm{b}^{2}\right)$. The whiteness index CIE was calculated using a formula $\mathrm{WI}_{\mathrm{CIE}}=\mathrm{Y}+800(\mathrm{xn}-\mathrm{x})+1700(\mathrm{yn}-\mathrm{y})$, where $\mathrm{Y}$ is the $\mathrm{Y}$-tristimulus value of the sample, $\mathrm{x}$ and $\mathrm{y}$ are the $\mathrm{x}$, $y$ chromaticity coordinates of the sample, and $x n$, yn are the chromaticity coordinates of the perfect diffuser.

Lipid oxidation was determined by measuring 2-thiobarbituric acid reactive substances (TBARS) according to Witte et al. [1970] method. The TBA values were determined for two different portions of each fillet and Carp Ham, and two replicate colorimetric analyses were made of each portion. The resulting colour was measured at $530 \mathrm{~nm}$ using a Varian Cary 300 Bio spectrophotometer (Varian Australia PTY, Ltd.). The TBA value was calculated by multiplying the absorbance by 5.2 (results expressed as milligram of malondialdehyde (MDA) produced per $\mathrm{kg}$ of tissue).

\section{Proximate composition}

The proximate composition of the carp fillets and Carp Hams were determined in duplicate, using conventional methods, i.e. moisture content (drying method, $103^{\circ} \mathrm{C}$ ) according to PN-ISO 1442:2000, ash content (combustion method in a muffle furnace, $550^{\circ} \mathrm{C}$ ) according to PN-ISO 936:2000, total protein content (Kjeldahl's method) using a Büchi B-324 apparatus (Flawil, Switzerland) according to PN-75/A-04018, and intramuscular lipids content (Soxhlet's method with n-hexane as the solvent) using a Büchi B-811 apparatus (Flawil, Switzerland) according to PNISO 1444:2000. The energetic value of $100 \mathrm{~g}$ of fillet or product was calculated based on the protein and fat content using Atwater's equivalents (protein $16.7 \mathrm{~kJ} / \mathrm{g}$ and fat $37.6 \mathrm{~kJ} / \mathrm{g}$ ). The salt content (sodium chloride) was analysed by using the Mohr method according to PN-A-82112:1973/Az1:2002, solely in the Carp Ham.

The index of nutritional quality (INQ) for the protein and fat was calculated using an equation specified by Hansen et al. [1979] and the reference intakes for energy and selected nutrients [EU, 2011].

\section{Fatty acid analyses}

The fatty acid content and profile were determined using the Varian 3900 gas chromatograph (Walnut Creek, CA USA) with a flame ionisation detector (FID) and a CP Sil 88 capillary column. The analysis of the fatty acid content was conducted after fat extraction with a mixture of chloroform/methanol using Folch et al. [1957] method. Further investigations concerning the fatty acid profile were performed in duplicate according to standards PN-EN ISO 5508: 1996 and PN-EN ISO 12966-2:2011. Fatty acids were expressed as percentages of the sum of the total identified fatty acids (wt.\%) using the Star GC Workstation Version 5.5. software. The mean value of the fatty acids identified was used to calculate the sum of the saturated (SFA), monounsaturated (MUFA), and polyunsaturated (PUFA), as well as n-3 and n-6, fatty acids. The following ratios were calculated: PUFA/SFA; n3/n6; and $\mathrm{h} / \mathrm{H}$ (hypocholesterolaemic/hypercholesterolaemic ra- tio). According to Ulbricht \& Southgate [1991], the AI (atherogenic index) and TI (thrombogenic index) indices were calculated. Peroxidability index (PI) was calculated according to the equation proposed by Arakawa \& Sagai [1986].

\section{Mineral analysis}

The samples ( $1 \mathrm{~g}$ ) of fillets or Carp Hams were wet-digested with $9 \mathrm{~mL}$ of concentrated nitric acid using the microwave oven MarsXpress (CEM Corporation, Matthews, NC, USA). Digested samples were transferred to polypropylene tubes and diluted to $25 \mathrm{~mL}$ with ultrapure water. A blank digest $\left(9 \mathrm{~mL}\right.$ of $\left.\mathrm{HNO}_{3}\right)$ was prepared in the same way. The concentration of major elements (K, Na, Ca, Mg) and minor elements ( $\mathrm{Zn}, \mathrm{Fe}, \mathrm{Mn}, \mathrm{Cu}$ ) was determined by means of the flame atomic absorption spectrometry (FAAS; air-acetylene flame) using a Varian Spectra 240FS spectrometer. During the analysis, the following detection limits (LOD) were taken into account: $0.01 \mathrm{mg} / \mathrm{kg}$ for $\mathrm{Na}, 0.04 \mathrm{mg} / \mathrm{kg}$ for $\mathrm{K}, 0.47 \mathrm{mg} / \mathrm{kg}$ for $\mathrm{Mg}, 0.22 \mathrm{mg} / \mathrm{kg}$ for $\mathrm{Ca}, 0.01 \mathrm{mg} / \mathrm{kg}$ for $\mathrm{Mn}, 0.01 \mathrm{mg} / \mathrm{kg}$ for $\mathrm{Cu}, 0.01 \mathrm{mg} / \mathrm{kg}$ for $\mathrm{Zn}$, and $0.09 \mathrm{mg} / \mathrm{kg}$ for Fe. The method's accuracy was evaluated by means of trace metals determined in the DORM-3 and 1546C Standard Reference Material. Analyses were performed in triplicate. The content of major and minor elements in the samples was expressed in $\mathrm{mg} / \mathrm{kg}$ wet mass.

\section{Statistical analysis}

The statistical analyses were performed using the SAS Enterprise Guide 6.1 software [SAS, 2013]. A one-way analysis of variance (ANOVA) followed, t-test for independent samples, was employed to compare the means of intrinsic properties, proximate composition, minerals concentration, and fatty acid composition of raw material (fillets) and product (Carp Ham). Differences between the means at the 95\% and $99 \%(\mathrm{P}<0.05$ and $\mathrm{P}<0.01)$ confidence levels were considered statistically significant.

\section{RESULTS AND DISCUSSION}

Table 2 presents the results of the measurements of the fish body (common carp) and fillets used to manufacture Carp Hams. The average slaughter yield of fish was similar to those observed by Tkaczewska \& Migdał [2012] for farmed carps in Poland (ranged from 51.2 to 59.4\%). Tokur et al. [2006] found that for mirror carp (C. carpio) between 700-800 g in weight, the obtained yield of flesh (without head and guts) averaged 38.14\%. Marcu et al. [2010] revealed a significant increase of carp slaughter yield from $50.68 \%$ for fish weighing $785 \mathrm{~g}$ to $60.28 \%$ for fish that were $2010 \mathrm{~g}$.

The appearance of Carp Ham was similar to products manufactured from the meat of homeothermic animals. A series of complex biochemical processes, including proteolysis, lipolysis and oxidation, take place during brining and smoking. These stages render a product with a firm consistency having the characteristic pleasant flavour and aroma as well as that is expected by consumers. However, the outlines of coiled fillets of fish were clearly visible in the cross-section (Figure 1). The external shape resembles an oval or ellipsoid with an irregular, wrinkled surface due to using netting to 
TABLE 2. Morphometric measurements of common carp and fillets $(n=12)$.

\begin{tabular}{lcccc}
\hline Measurement & Mean value & Stand. dev. & Min-max. \\
\hline Total weight $(\mathrm{g})$ & 938.0 & 131.6 & $710.1-1097.1$ \\
Total length (cm) & 39.4 & 2.1 & $36.0-42.5$ \\
Body length (cm) & 32.3 & 2.23 & $29.0-36.1$ \\
Max height (cm) & 11.6 & 0.56 & $10.8-12.3$ \\
Min height (cm) & 4.4 & 0.14 & $4.2-4.6$ \\
Body width (cm) & 5.0 & 0.17 & $4.7-5.2$ \\
\hline \multicolumn{5}{c}{ Skeleton } \\
\hline Weight (g) & 134.3 & 29.8 & $109.4-199.3$ \\
Share (\%) & 15.23 & 1.70 & $13.3-18.2$ \\
\hline \multicolumn{5}{c}{ Fillet and skin } \\
\hline Weight (g) & 389.9 & 47.1 & $301.0-432.0$ \\
Share (\%) & 41.72 & 1.96 & $39.4-43.7$ \\
\hline
\end{tabular}

TABLE 3. Results of physical measurements of Carp Ham $(n=6)$.

\begin{tabular}{lcccc}
\hline Measurement & Mean value & Stand. dev. & Min-max. \\
\hline Total weight $(\mathrm{g})$ & 290.5 & 21.05 & $256.8-320.9$ \\
Net weight $(\mathrm{g})$ & 275.4 & 25.82 & $237.0-312.4$ \\
Length $(\mathrm{cm})$ & 11.9 & 0.66 & $10.8-12.8$ \\
Diameter $(\mathrm{cm})$ & 6.2 & 0.37 & $5.6-6.7$ \\
Circumference $(\mathrm{cm})$ & 20.4 & 0.79 & $19.0-21.5$ \\
\hline
\end{tabular}

form the product. A cross-section of Carp Ham was nearly round or oval. The descriptive values of the physical measurements are shown in Table 3. The consistency of the product was compact, firm to the touch and suitable for vertical cutting. The flavour of Carp Ham was slightly salty and typical for smoked fish, with an aroma of smoke from non-coniferous wood, mainly alder. The colour of the external Carp Ham's surface was typical for smoked products, brown with different tinges. The internal surface was white with slight pink (natural tint of carp fillets) or brown (natural tint of carp skin) colouration.

The colour parameters were determined to evaluate the effect of processing on the fillet of carp. The results obtained are shown in Table 4. Manufacturing (heat, protein denaturation and dehydration) significantly influenced all CIE colour parameters $\left(L^{*}, b^{*}\right.$ and $\left.C^{*}, P<0.05 ; h^{\circ}, P<0.01\right)$, with the exception of the $\mathrm{a}^{*}$ coordinate. The cross-section surface of Carp Ham was lighter, less red, more yellow, and more intense in colour than was the fresh fillet. The negative value of the $b^{*}$ coordinate indicates a bluish tint on the fillet's surface, with a high value of the hue angle $\left(h^{\circ}=352.84\right)$ in comparison with Carp Ham surface $\left(h^{\circ}=4.12\right)$. The degree of whiteness is measured by the degree of departure of the object from a perfect white. Despite considerable difference between mean values of the whiteness index for raw fillets and the final product no significant difference was detected relevant to this characteristic $(\mathrm{P}>0.05)$. Moreover, the increase of $\mathrm{L}^{*}$ value should indicate a "whitening" of the final product. However, an opposing and remarkable decrease of the whiteness index (and concomitant standard deviation) in Carp Ham was observed. The lightness value $\left(\mathrm{L}^{*}\right)$ for the raw fillets of common carp found in this study is in accordance with those reported earlier by Hong et al. [2012] in bighead carp fillets $\left(L^{*}=51.01\right)$, and by Shi et al. [2014] in silver carp fillets $\left(L^{*}=51.4\right)$. However, no previous study was found regarding the colour changes of smoked carp products similar to that being investigated in the present work.

The mean initial $\mathrm{pH}$ value of the fillets was similar to the value determined in Carp Ham (Table 4). The $\mathrm{pH}$ of raw carp muscle tissue in the present study was very similar to the result reported by Shi et al. [2014] for silver carp but was lower than the value (7.28) reported by Hong et al. [2012] for bighead carp, and simultaneously was slightly higher than was the value of 6.58 determined by Zhu et al. [2013] in crisp grass carp fillets.

In the same way, in the present study the 2-thiobarbituric acid (TBA) value of both the initial fillet samples and the Carp Hams were similar. The TBA value of the fresh carp fillet in this study was higher than was the value reported for the muscle tissue of the carp (0.345 MDA $/ \mathrm{kg}$ tissue) that had a higher lipid fat content $(2.61 \%)$ [Dembele et al., 2010], and similar to that reported for mangar (Luciobarbus esocinus) fillet ( $0.59 \mathrm{mg} \mathrm{MDA} / \mathrm{kg}$ tissue), with a lipid content of $6.23 \%$. Likewise, it is also similar to the farmed brown trout fillet $(0.65 \mathrm{mg} \mathrm{MDA} / \mathrm{kg})$, with a lipid content of $3.16 \%$ [Dal Bosco et al., 2013]. TBA is widely used as an indicator of the degree of lipid oxidation, and the presence of TBAreactive substances is due to the second stage auto-oxidation where peroxides are oxidised to aldehydes and ketones. The data revealed that the manufacturing process (salting, smoking) can extend the preservation of fillets by inhibit-

TABLE 4. The $\mathrm{pH}$, TBA value and colour parameters of fillet and Carp Ham (mean \pm s.d.).

\begin{tabular}{lcc}
\hline Trait & $\begin{array}{c}\text { Fillet } \\
\mathrm{n}=12\end{array}$ & $\begin{array}{c}\text { Carp Ham } \\
\mathrm{n}=6\end{array}$ \\
\hline $\mathrm{pH}$ & $6.87 \pm 0.12$ & $6.77 \pm 0.07$ \\
$\mathrm{TBA}(\mathrm{mg}$ MDA/kg) & $0.60 \pm 0.13$ & $0.64 \pm 0.10$ \\
\hline $\mathrm{CIE}$ & & \\
\hline $\mathrm{L}^{*}$ & $50.86 \pm 2.69^{\mathrm{a}}$ & $55.62 \pm 3.74^{\mathrm{b}}$ \\
$\mathrm{a}^{*}$ & $13.60 \pm 2.47$ & $11.14 \pm 1.05$ \\
$\mathrm{~b}^{*}$ & $-1.65 \pm 0.41^{\mathrm{A}}$ & $0.83 \pm 0.78^{\mathrm{B}}$ \\
$\mathrm{C}^{*}$ & $13.70 \pm 2.43^{\mathrm{b}}$ & $11.18 \pm 1.08^{\mathrm{a}}$ \\
$\mathrm{h}^{\circ}$ & $352.84 \pm 2.52^{\mathrm{B}}$ & $4.12 \pm 3.66^{\mathrm{A}}$ \\
$\Delta \mathrm{E}$ & \multicolumn{2}{c}{$6.99 \pm 1.64$} \\
$\mathrm{WI}_{\mathrm{CIE}}$ & $32.40 \pm 8.03$ & $23.81 \pm 7.09$ \\
\hline
\end{tabular}

Means with different letters within row are significantly different: $a, b-$ $\mathrm{P}<0.05 ; \mathrm{A}, \mathrm{B}-\mathrm{P}<0.01$. 
ing oxidation of the lipids in fish, in spite of significant fat contents (Table 5). Because a fillet has a large surface that is exposed to oxygen, it is prone to oxidation more than is the whole fish (without being gutted) or the product after preservative treatments. This observation is in agreement with the results reported by Yanar \& Fenercioglu [1998] for fish balls made from carp and by Gelman \& Benjamin [1989] for minced pond-bred flesh of silver carp.

The proximate analysis was determined in the raw fillet samples and after Carp Ham manufacturing (Table 5). The process, however, includes diffusion of salt into the fish and the elimination of water through the process of osmosis. Such transfer of moisture from the fish flesh due to osmosis resulted in a decrease of moisture content, with a simultaneous increase of ash content of the final product. Moreover, as a result of dehydration, the relative lipid and salt content increased through the process of smoking [Vasiliadou et al., 2005]. The mean contents of all solid compounds (protein, fat and ash) in $100 \mathrm{~g}$ of the traditional product were significantly $(\mathrm{P}<0.01)$ higher than in fillets, with an obvious exception of the moisture content. The results referring to changes of dry matter content are in agreement with those observed by Szathmári \& Molnár [2007] in common carp (collected in June) before (25.89\%) and after cold $(33.18 \%)$ or hot (35.88\%) smoking.

The INQ value for protein in Carp Ham was significantly lower than in raw fillets, however, the opposite relation was stated in the case of INF for fat. Generally, the INQ of fish flesh is greater than is the index for eggs (hen). What is more, it is two times higher in relation to dairy and meat products [Kołakowska \& Kolakowski, 2001]. The present study revealed that both, carp fillet and final product were a good source of protein, as can be seen from the high values of INQ. Moreover, a high value (above 1) of INQ for fat was determined also for Carp Ham.

The energetic value of fish indicates the content of basic chemical components, and in particular, of fat. In the present study, a significantly $(\mathrm{P}<0.01)$ higher energy value was found

TABLE 5. Proximate composition, and nutritional indices of fillet and Carp Ham (mean \pm s.d.).

\begin{tabular}{lccc}
\hline Compound/Index & $\begin{array}{c}\text { Fillet } \\
\mathrm{n}=12\end{array}$ & $\begin{array}{c}\text { Carp Ham } \\
\mathrm{n}=6\end{array}$ \\
\hline Moisture $(\mathrm{g} / 100 \mathrm{~g})$ & $77.79 \pm 1.00^{\mathrm{B}}$ & $63.60 \pm 1.17^{\mathrm{A}}$ \\
Ash $(\mathrm{g} / 100 \mathrm{~g})$ & $1.22 \pm 0.06^{\mathrm{A}}$ & $6.58 \pm 1.45^{\mathrm{B}}$ \\
Protein $(\mathrm{g} / 100 \mathrm{~g})$ & $19.28 \pm 1.12^{\mathrm{A}}$ & $21.94 \pm 0.79^{\mathrm{B}}$ \\
Lipid $(\mathrm{g} / 100 \mathrm{~g})$ & $1.53 \pm 0.58^{\mathrm{A}}$ & $8.63 \pm 3.05^{\mathrm{B}}$ \\
NaCl $(\mathrm{g} / 100 \mathrm{~g})$ & - & $7.78 \pm 0.60$ \\
Calorific value & $384 \pm 13^{\mathrm{A}}$ & $692 \pm 102^{\mathrm{B}}$ \\
$(\mathrm{kJ} / 100 \mathrm{~g})$ & $8.43 \pm 0.54^{\mathrm{B}}$ & $5.44 \pm 0.93^{\mathrm{A}}$ \\
INQ protein & $0.48 \pm 0.18^{\mathrm{A}}$ & $1.46 \pm 0.31^{\mathrm{B}}$ \\
INQ fat & &
\end{tabular}

Means with different letters within row are significantly different: A,B $\mathrm{P}<0.01$. for Carp Ham as compared to raw fillets, as a consequence of higher content of fat and protein. The most crucial factors determining the share of lipids in the muscle tissue of fish include: species, age and maturity of fish, as well as climate, temperature, water pollution (fishery) and the availability and type of food [Guler et al., 2008; Ligaszewski et al., 2007]. In general, the energetic value, even for very fatty fish, is lower compared to other products of animal origin. Hadjinikolova et al. [2008] reported the energy value of carp fillets at a higher level, with results ranging from 437 to $445 \mathrm{~kJ} / 100 \mathrm{~g}$.

The salt content of Carp Ham was found to be $7.78 \%$. Our result was opposite to the other authors' studies. Majumdar \& Basu [2010] reported higher content of salt (15.75\%) for the Indian traditional salt fermented fish product (Lona ilish). Contrary, Alcicek \& Atar [2010] reported lower values (ranged between 3 and 6\%) for traditional smoked rainbow trout fillets, whereas Espe et al. [2004] revealed even a lower range $(1.3-3.4 \%)$ for cold smoked Atlantic salmon. The low salt concentration in fish products may have implicationa for food safety, due to the presence of Clostridium botulinum in the natural aquatic environment. Toxin production by psychrotrophic types of Clostridium botulinum in cold smoked fish is recommended to be controlled by a combination of $3.5 \% \mathrm{NaCl}$ in the water phase of the product and storage at chilled temperatures below $4.4^{\circ} \mathrm{C}$ [Gram, 2001].

Furthermore, $\mathrm{NaCl}$ has a pro-oxidative effect that enhances the activity of iron toward lipid oxidation, which is positively correlated with the yellowness ( $b^{*}$ ) of brined fish [Hong et al., 2012]. Similar results were reported in the present study, however, the significantly higher value of $b^{*}$ detected in Carp Ham in comparison with raw fillets was not related to the greater lipid oxidation expressed by TBA value.

The mineral components in the raw fillets and the final product are shown in Table 6 . Of these, $\mathrm{K}$ was quantitatively the most important in the raw tissue, followed by $\mathrm{Na}$ and $\mathrm{Mg}$, except in the smoked product, where $\mathrm{Na}$ from the added salt predominates. The presented results of major element ( $\mathrm{Na}, \mathrm{K}, \mathrm{Mg}$ and $\mathrm{Ca}$ ) concentrations in common carp fillets

TABLE 6. Mineral contents (mg/kg) in fillet and Carp Ham (mean \pm s.d.).

\begin{tabular}{lcc}
\hline Minerals & $\begin{array}{c}\text { Fillet } \\
\mathrm{n}=12\end{array}$ & $\begin{array}{c}\text { Carp Ham } \\
\mathrm{n}=6\end{array}$ \\
\hline \multicolumn{3}{c}{ Major elements } \\
\hline $\mathrm{Na}$ & $298.8 \pm 26.6^{\mathrm{A}}$ & $22649.6 \pm 9735.9^{\mathrm{B}}$ \\
$\mathrm{K}$ & $3667.9 \pm 216.7^{\mathrm{b}}$ & $3107.8 \pm 435.6^{\mathrm{a}}$ \\
$\mathrm{Mg}$ & $285.7 \pm 10.7^{\mathrm{b}}$ & $236.2 \pm 34.1^{\mathrm{a}}$ \\
$\mathrm{Ca}$ & $252.1 \pm 51.5^{\mathrm{b}}$ & $107.7 \pm 15.3^{\mathrm{a}}$ \\
\hline & Minor elements \\
\hline $\mathrm{Fe}$ & $1.70 \pm 0.52$ & $2.10 \pm 0.66$ \\
$\mathrm{Zn}$ & $2.49 \pm 0.21^{\mathrm{a}}$ & $3.10 \pm 0.37^{\mathrm{b}}$ \\
$\mathrm{Mn}$ & $0.19 \pm 0.02^{\mathrm{A}}$ & $0.50 \pm 0.11^{\mathrm{B}}$ \\
$\mathrm{Cu}$ & $0.13 \pm 0.04$ & $0.16 \pm 0.09$ \\
\hline
\end{tabular}

Means with different letters within row are significantly different: $a, b-$ $\mathrm{P}<0.05 ; \mathrm{A}, \mathrm{B}-\mathrm{P}<0.01$. 
TABLE 7. Fatty acid methyl ester composition, ratios and indices of fillet and Carp Ham (mean \pm s.d.).

\begin{tabular}{|c|c|c|}
\hline Fatty acid & $\begin{array}{l}\text { Fillet } \\
\mathrm{n}=12\end{array}$ & $\begin{array}{c}\text { Carp Ham } \\
\mathrm{n}=6 \\
\end{array}$ \\
\hline \multicolumn{3}{|c|}{ Individual fatty acids ( $\%$ total fatty acids) } \\
\hline C $14: 0$ & $1.36 \pm 0.22$ & $1.28 \pm 0.09$ \\
\hline C $16: 0$ & $17.70 \pm 1.49$ & $17.93 \pm 0.77$ \\
\hline C $16: 1$ n-9 & $5.65 \pm 0.97$ & $6.12 \pm 1.20$ \\
\hline C $18: 0$ & $5.48 \pm 0.59$ & $4.90 \pm 0.51$ \\
\hline C $18: 1 \mathrm{n}-7$ & $3.16 \pm 0.62$ & $2.85 \pm 0.27$ \\
\hline C $18: 1$ n-9 & $37.25 \pm 6.17$ & $37.47 \pm 6.71$ \\
\hline C 18:2 n-6 LA & $16.27 \pm 4.29$ & $18.06 \pm 6.93$ \\
\hline C 18:3 n-3 ALA & $2.97 \pm 1.33$ & $2.45 \pm 0.92$ \\
\hline C $20: 1 \mathrm{n}-9$ & $2.22 \pm 0.38^{\mathrm{b}}$ & $1.76 \pm 0.31^{\mathrm{a}}$ \\
\hline C 20:4 n-6 AA & $1.18 \pm 0.38$ & $1.05 \pm 0.32$ \\
\hline C 20:5 n-3 EPA & $1.48 \pm 0.92$ & $1.04 \pm 0.41$ \\
\hline C 22:5 n-3 DPA & $0.46 \pm 0.13$ & $0.33 \pm 0.12$ \\
\hline C 22:6 n-3 DHA & $1.34 \pm 0.17^{\mathrm{B}}$ & $0.83 \pm 0.28^{\mathrm{A}}$ \\
\hline \multicolumn{3}{|c|}{ Sum } \\
\hline SFA & $25.43 \pm 1.44$ & $24.81 \pm 1.12$ \\
\hline MUFA & $49.75 \pm 5.90$ & $49.55 \pm 8.21$ \\
\hline PUFA & $24.80 \pm 5.55$ & $25.62 \pm 8.84$ \\
\hline$n-3$ & $6.28 \pm 2.29$ & $4.67 \pm 1.68$ \\
\hline$n-6$ & $17.50 \pm 4.28$ & $19.27 \pm 7.09$ \\
\hline \multicolumn{3}{|c|}{ Ratios } \\
\hline $\mathrm{P} / \mathrm{S}$ & $0.98 \pm 0.22$ & $1.04 \pm 0.39$ \\
\hline$n-3 / n-6$ & $0.37 \pm 0.15$ & $0.24 \pm 0.03$ \\
\hline $\mathrm{h} / \mathrm{H}$ & $3.23 \pm 0.42$ & $3.20 \pm 0.23$ \\
\hline \multicolumn{3}{|c|}{ Indices } \\
\hline AI & $0.31 \pm 0.04$ & $0.31 \pm 0.01$ \\
\hline TI & $0.47 \pm 0.04$ & $0.50 \pm 0.07$ \\
\hline PI & $51.95 \pm 9.75$ & $45.92 \pm 14.45$ \\
\hline
\end{tabular}

SFA - saturated fatty acids; MUFA - monounsaturated fatty acids; PUFA - polyunsaturated fatty acids; P/S - PUFA/SFA ratio; n3/n6: sum of $n-3$ fatty acids/sum of $n-6$ fatty acids; $h / H$ - hypocholesterolemic/hypercholesterolemic ratio $=(\mathrm{C} 18: 1 \mathrm{c} 9+\mathrm{C} 18: 2 \mathrm{c} 9 \mathrm{c} 12 \mathrm{n} 6+\mathrm{C} 18: 3 \mathrm{c} 6 \mathrm{c} 9 \mathrm{c} 12 \mathrm{n} 6+\mathrm{C}$ $18: 3 \mathrm{c} 9 \mathrm{c} 12 \mathrm{c} 15 \mathrm{n} 3+\mathrm{C} 20: 2 \mathrm{c} 11 \mathrm{c} 14 \mathrm{n} 6+\mathrm{C} 20: 4 \mathrm{n} 6+\mathrm{C} 20: 3 \mathrm{c} 8 \mathrm{c} 11 \mathrm{c} 14 \mathrm{n} 6+\mathrm{C} 20: 3$ $\mathrm{c} 11 \mathrm{c} 14 \mathrm{c} 17 \mathrm{n} 3+\mathrm{C} 20: 5 \mathrm{n} 3+\mathrm{C} 22: 5 \mathrm{n} 3+\mathrm{C} 22: 6 \mathrm{n} 3) /(\mathrm{C} 12: 0+\mathrm{C} 14: 0+\mathrm{C} 16: 0)$ $\mathrm{AI}$ - atherogenic index $(\mathrm{C} 12: 0+4 \times \mathrm{C} 14: 0+\mathrm{C} 16: 0) /(\mathrm{MUFA}+\mathrm{n} 6+\mathrm{n} 3)$; TI - thrombogenic index $(\mathrm{C} 14: 0+\mathrm{C} 16: 0+\mathrm{C} 18: 0) /(0.5 \times \mathrm{MUFA}+0.5 \mathrm{x}$ $\mathrm{n} 6+3 \times \mathrm{n} 3+\mathrm{n} 3 / \mathrm{n} 6) ; \mathrm{PI}-$ peroxidability index $=(\%$ monoenoic $\mathrm{x} 0.025)+$ $(\%$ dienoic $\times 1)+(\%$ trienoic $\times 2)+(\%$ tetraenoic $\times 4)+(\%$ pentaenoic $\mathrm{x}$ 6) $+(\%$ hexaenoic $x 8)$

Means with different letters within row are significantly different: $a, b-$ $\mathrm{P}<0.05 ; \mathrm{A}, \mathrm{B}-\mathrm{P}<0.01$.

were similar to those reported by Łuczyńska et al. [2011] for muscle tissue of carp from retail (weighted 970-1250 g) and Brucka-Jastrzębska et al. [2009] for muscles of carp aged
6-12 months. However, $\mathrm{Mn}$ and $\mathrm{Cu}$ contents recorded in this study were not high and remained within the normal range for cyprinids (Cyprinidae) that has been reported in the previous study [Skałecki et al., 2015].

In this investigation, the processing had a significant influence $(\mathrm{P}<0.05)$ on a decrease of major elements in Carp Ham and an increase of minor element concentrations. However, differences in the content of $\mathrm{Fe}$ and $\mathrm{Cu}$ in both, the fillet and Carp Ham were insignificant $(\mathrm{P}>0.05)$. Nevertheless, the significantly $(\mathrm{P}<0.01)$ higher $\mathrm{Na}$ concentration in the final product $(22,649.6 \mathrm{mg} / \mathrm{kg})$ was due to the effect of fillets brining before smoking. Staszowska et al. [2013] also reported that smoking significantly influenced higher concentrations of $\mathrm{Na}, \mathrm{K}, \mathrm{Ca}$ and $\mathrm{Zn}$ in rainbow trout, however, the concentrations of $\mathrm{Mg}, \mathrm{Zn}, \mathrm{Mn}$ and $\mathrm{Cu}$ in raw and smoked fish were similar.

Table 7 summarized results of the fatty acid composition, calculated ratios and indices of the carp fillets and Carp Ham. The only significant differences were stated for $\mathrm{C} 20: 1 \mathrm{n}-9$ $(\mathrm{P}<0.05)$ and $\mathrm{C} 22: 6 \mathrm{n}-3 \quad(\mathrm{P}<0.01)$, with the higher values determined for fillets than the product. Concerning the fatty acid content, both in fillets and Carp Ham, the major SFA, MUFA and PUFA were palmitic (C16:0), oleic (C18:1n-9) and linoleic acid (C18:2n-6), respectively. Similar to our findings, these acids were reported to be the predominant fatty acids in common carp [Trbović et al., 2013]. In contrast, Dembele et al. [2010] and Pirestani et al. [2010] found other dominant acids among PUFA, i.e. C18:3n-6, as well as DHA and EPA, respectively. According to Mráz \& Pickova [2009], the percentage of n-3 PUFA in fillets from the common carp is affected by the lipid content of the fish $\left(\mathrm{R}^{2}=0.90\right)$, and different fatty acid metabolism. Also, plankton was the additional source of highly unsaturated fatty acids (EPA and DHA) in the carp muscle.

It has been emphasised that fish that are rich in terms of the n-3 and n-6 forms of polyunsaturated fatty acids (PUFAs) are beneficial for human health [Ackman, 2008]. Among the long-chain PUFAs in fish tissues, intensive efforts have focused on eicosapentaenoic (C20:5 n-3, EPA), docosapentaenoic (C22:5 n-3, DPA), and docosahexaenoic acid (C22:6 n-3, DHA), due to their nutritive importance [Weichselbaum et al., 2012] and protective effects against coronary heart diseases, neurodegenerative diseases and plurimetabolic syndrome [FAO \& WHO, 2010]. In the present study, the contents of EPA+DPA+DHA in fresh fillets and Carp Hams were determined to be $3.28 \%$ and $2.20 \%$.

The information concerning the nutritional value of the final product is of importance, both to the producers and the consumers. The contents of EPA and DHA found in this study for the common carp are higher than these reported by Trbović et al. [2013] in a work developed in Serbia, where the EPA and DHA percentages in carp (874 $\mathrm{g}$ of weight and $2.37 \%$ lipid content) were 0.96 and $0.81 \%$, respectively. Contrary, Pirestani et al. [2010], when studying common carp ( $830 \mathrm{~g}$ of weight and $6.31 \%$ of lipid content) from the South Caspian Sea, obtained the percentages of EPA and DHA at $5.31 \%$ and $6.20 \%$. On the other hand, the total PUFAs was lower at $15.8 \%$, but the total SFA was higher at $36 \%$ than in the presented study. Similarly, the higher sum of PU- 
FAs in the meat of common carp (C. carpio) was reported by Dembele et al. [2010] and Guler et al. [2008].

It is widely accepted that a high $n-3 / n-6$ fatty acid ratio is beneficial to health, particularly with regard to reducing the risk of cardiovascular disease [Simopoulos, 2008]. Steffens [1997] reported that freshwater fish contain higher levels of n-6 PUFA, resulting in a much lower n-3/n-6 FA ratio (ranging from 1 to 4) compared with marine fish (ranging from 5 to 10). The $n-3 / n-6$ ratio determined in the present study was lower than those revealed for common carp by Łuczyńska et al. [2011] (0.71) and Pirestani et al. [2010] (3.34). It was a consequence of both, the high amount of LA acid (C18:2 n-6), and the low total n-3 acids. However, the lower percentage of n-3 acids in Polish carps (1.96\%) was reported earlier by Kołakowska et al. [2000]. According to Steffens \& Wirth [2007], as well as Ligaszewski et al. [2007], the percentages of n-6 and n-3 fatty acids in carp meat depend on fish-feed or the profile of unsaturated fatty acids in zooplankton.

The data obtained in this study showed that there is a tendency towards decreasing levels of $\mathrm{n}-3$, with concomitant increasing levels of the n-6 PUFA after fillet processing for Carp Ham. However, the significant difference was found only for the DHA acid. Domiszewski [2013] revealed that the heating of trout and sprats minced tissue at temperatures of 60 , 100 and $160^{\circ} \mathrm{C}$, even for $1-2 \mathrm{~h}$, did not evoke losses, either in EPA or in DHA content, but in the case of herring, the heat treatment applied for $90-120$ min contributed to $20-25 \%$ decrease in the contents of these fatty acids.

The ratio between hypocholesterolaemic and hypercholesterolaemic fatty acids, indicating the effects of specific fatty acids on cholesterol metabolism (wherein a higher value of $\mathrm{h} / \mathrm{H}$ is more desirable), did not differ $(\mathrm{P}>0.05)$ between fresh carp fillets and the final product. Also, the $\mathrm{h} / \mathrm{H}$ ratio in carp fillets in the present study was general higher than that found by Testi et al. [2006] in sea bass (2.03-2.18), sea bream (2.07-2.20), and rainbow trout (2.40-2.46), and by Dal Bosco et al. [2013] in brown trout (1.88-2.16).

The atherogenic index (AI) is considered as a health indicator related to the risk of cardiovascular diseases (microand macro-coronary diseases). Index of thrombogenicity (TI) shows the tendency to form clots in the blood vessels. This is defined as the relationship between the prothrombogenetic (saturated) and the antithrombogenetic fatty acids (MUFA, n-6 PUFA, and n-3 PUFA). No significant differences $(\mathrm{P}>0.05)$ were observed in the TI and AI values between the raw fillets and the final product. Concerning the AI value obtained in the fillets, it was lower than the values reported for brown trout by Dal Bosco et al. [2013] (0.64-0.72) and Turchini et al. [2003] (0.45). However, the TI value obtained in carp fillets was higher compared to reported by Dal Bosco et al. [2013] for farmed and wild brown trout (0.21 and 0.30).

The peroxidisability index (PI) represents the relationship between the fatty acid composition of a tissue and its susceptibility to oxidation and supplied some information about the technological quality of the fillets. Fresh fillets showed a higher (but not significant) value of PI compared with the final product. However, many authors reported higher levels of PI in fillets of different fish. Dal Bosco et al. [2013], reported that in the muscle tissue of wild and cultivated brown trout, PI averaged 189.79 and 301.05, respectively. Also Testi et al. [2006] revealed a higher range of PI values in fillets of sea bass (from 163 to 192), sea bream (from 155 to 170), and rainbow trout (from 220 to 227).

\section{CONCLUSION}

The present study indicated that, as much as possible, the traditional manufacturing method retains most of the nutritional constituents present in the initial common carp fillets. Therefore, it can be used as an effective method for the processing of common carp, enabling manufacturers to produce the high quality traditional product, Carp Ham.

However, on the basis of the presented results, remarkable differences in the proximate composition and mineral contents emerged between the raw fillets and the final product, even though these differences were not of equal importance for the overall nutritional value. In this respect, it should be emphasised that the traditional product, Carp Ham, preserved positive nutritional features, which were better highlighted by the polyunsaturated fatty acid composition (unfortunately, excluding n-3 FA), health-related indices and oxidative stability.

\section{RESEARCH FUNDING}

Study financed from statutory activity.

\section{CONFLICT OF INTEREST}

None declared.

\section{REFERENCES}

1. Ackman R.G., Fatty acids in fish and shellfish. 2008, in: Fatty Acids in Foods and Their Health Implications (ed. C.K. Chow). CRC Press, London. pp. 155-185.

2. Alcicek Z., Atar H.H., The effects on chemical quality of vacuum packed liquid smoked and traditional smoked rainbow trout (Oncorhyncus mykiss) fillets during chilled storage. J. Anim. Vet. Adv., 2010, 9, 2778-2783.

3. Arakawa K., Sagai M., Species differences in lipid peroxide levels in lung tissue and investigation of their determining factors. Lipids, 1986, 21, 769-775.

4. Brucka-Jastrzębska E., Kawczuga D., Rajkowska M., Protasowicki M., Levels of microelements $(\mathrm{Cu}, \mathrm{Zn}, \mathrm{Fe})$ and macroelements (Mg, Ca) in freshwater fish. J. Elementol., 2009, 14, 437-447.

5. CIE, Colorimetry ( $3^{\text {rd }}$ ed.) 2004, Commission International de l'Eclairage. Vienne Austria pp. 16-20.

6. Dal Bosco A., Mugnai C., Roscini V., Castellini C., Fillet fatty acid composition, estimated indexes of lipid metabolism and oxidative status of wild and farmed brown trout (Salmo trutta L.). Ital. J. Food Sci., 2013, 25, 83-89.

7. Dembele S., Wang D.F., Yu L.N., Sun J.P., Dong S.Y., Effects of added crude green tea polyphenol on the lipid oxidation of common carp (Cyprinus carpio L.) and catfish (Clarias gariepinus Burchell) during refrigerated storage. J. Muscle Foods, 2010, 21, 738-756. 
8. Domiszewski Z., Effect of heating fatty fish: Baltic herring (Clupea harengus membras), European sprat (Sprattus sprattus) and rainbow trout (Oncorhynchus mykiss) on lipid oxidation and contents of eicosapentaenoic and docosahexaenoic acids. Int. J. Food Sci. Tech., 2013, 48, 786-793.

9. EC (European Community), Commission implementing regulation (EU) No 485/2011 of 18 May 2011 entering a name in the register of protected designations of origin and protected geographical indications (Karp zatorski (PDO)). OJ L 133, 20.05.2011, p. 6.

10. Espe M., Kiessling A., Lunestad B-T., Torrissen O.J., Rørå A.MmB., Quality of cold smoked salmon collected in one French hypermarket during a period of 1 year. LWT - Food Sci. Technol., 2004, 37, 627-638.

11. EU, Regulation (EU) No 1169/2011 of the European Parliament and of the Council of 25 October 2011, Annex XIII (OJ L 304, 22.11.2011, p. 18).

12. FAO and WHO, Fats and fatty acids in human nutrition. Report of an expert consultation. 2010, FAO Food and Nutrition Paper, 91. FAO, Rome.

13. FAO, The State of World Fisheries and Aquaculture. 2012, FAO/ WHO, Rome.

14. Folch J., Less M., Sloane G.H., A simple method for the isolation and purification of total lipids from animal tissue. J. Biol. Chem., 1957, 226, 497-509.

15. Gelman A., Benjamin E., Characteristics of mince from pondbred silvercarp (Hypophthalmichthys molitrix) and preliminary experiments on its use in sausages. J. Sci. Food Agric., 1989, 47, 225-241.

16. Gram L., Potential hazards in cold-smoked fish: Clostridium botulinum type E. J. Food Sci., 2001, 66, S1082-S1087.

17. Guler G.O., Kiztanir B., Aktumsek A., Citil O.B., Ozparlak H., Determination of the seasonal changes on total fatty acid composition and $\omega 3 / \omega 6$ rations of carp (Cyprinus carpio L.) muscle lipids in Beysehir Lake (Turkey). Food Chem., 2008, 108, 689$-694$.

18. Hadjinikolova L., Nikolova L., Stoeva A., Comparative investigations on the nutritive value of carp fish meat (cyprinidae), grown at organic aquaculture conditions. Bul. J. Agric. Sci., 2008, 14, 127-132.

19. Hansen R.G., Wyse B.W., Sorenson A.W., Nutrition Quality Index of Food. 1979, AVI Publishing Co., Westport, CT.

20. Hong H., Luo Y., Zhou Z., Shen H., Effects of low concentration of salt and sucrose on the quality of bighead carp (Aristichthys nobilis) fillets stored at $4^{\circ} \mathrm{C}$. Food Chem., 2012, 133, 102-107.

21. Hryszko K., Fish market. State and prospects. 2013, IERiGŻPIB, Warszawa, 20, pp. 20-27 (in Polish, English abstract).

22. Kołakowska A., Kołakowski E., The specific nutritional properties of fish. Przem. Spoż., 2001, 6, 10-13 (in Polish, English abstract).

23. Kołakowska A., Szczygielski M., Bienkiewicz G., Zienkowicz L., Some of fish species as a source of n-3 polyunsaturated fatty acids. Acta Ichthyol. Piscat., 2000, 30, 59-70.

24. Ligaszewski M., Węglarz K., Pilarczyk A., Łysak A., Bereza M., Relation between the profile of major fractions of unsaturated fatty acids in common carp meat (Cyprinus carpio L.) in the second year of life and their profile in zooplankton. Pol. J. Food Nutr. Sci., 2007, 3A (57), 77-81.
25. Łuczyńska J., Tońska E., Borejszo Z., Content of macro- and microelements, and fatty acids in muscles of salmon (Salmo salar L.), rainbow trout (Oncorhynchus mykiss Walb.), and carp (Cyprinus carpio L.). Żywność. Nauka. Technologia. Jakość, 2011, 18, 162-172 (in Polish, English abstract).

26. Majumdar R.K., Basu S., Characterization of the traditional fermented fish product Lona ilish of Northeast India. Indian J. Traditional Knowledge, 2010, 9, 453-458.

27. Marcu A., Nichita I., Nicula M., Marcu B., Kelciov A., Studies regarding the meat quality of the species Cyprinus carpio. Lucrări Ştiințifice - Seria Medicină Veterinară, 2010, 43, 2, 265-270.

28. MARD, List of Traditional Products. 2015. Polish Ministry of Agriculture and Rural Development. [http://www.minrol. gov.pl/Jakosc-zywnosci/Produkty-regionalne-i-tradycyjne/Listaproduktow-tradycyjnych/(pid)/332]. (accessed August 20, 2015).

29. Mráz J., Pickova J., Differences between lipid content and composition of different parts of fillets from crossbred farmed carp (Cyprinus carpio). Fish Physiol. Biochem., 2009, 35, 615-623.

30. Pirestani S., Sahari M.A., Barzegar M., Nikoopour H., Lipid, cholesterol and fatty acid profile of some commercially important fish species from South Caspian Sea. J. Food Biochem., 2010, 34, 886-895.

31. PN-A-04018. 1975. Agricultural food products - Determination of nitrogen by Kjeldahl method and expressing as protein (in Polish).

32. PN-A-82112:1973/Az1:2002. Meat and meat products - Determination of salt content (in Polish).

33. PN-EN ISO 12966-2:2011 Animal and vegetable fats and oils Gas chromatography of fatty acid methyl esters - Part 2: Preparation of methyl esters of fatty acids (in Polish).

34. PN-EN ISO 5508: 1996. Animal and vegetable fats and oils Gas chromatography of fatty acid methyl esters (in Polish).

35. PN-ISO 1442. 2000. Meat and meat products - Determination of moisture content (reference method) (in Polish).

36. PN-ISO 1444. 2000. Meat and meat products - Determination of free fat content (in Polish).

37. PN-ISO 936. 2000. Meat and meat products - Determination of total ash (in Polish).

38. SAS, Enterprise Guide 6.1. 2013, SAS Institute Inc., Cary, NC, USA.

39. Shi C., Cui J., Luo Y, Zhou Z., Effect of lightly salt and sucrose on rigor mortis changes in silver carp (Hypophthalmichthys molitrix) stored at $4^{\circ} \mathrm{C}$. Int. J. Food Sci. Tech., 2014, 49, 160-167.

40. Simopoulos A.P., The omega-6/omega-3 fatty acid ratio, genetic variation, and cardiovascular disease. Asia Pac. J. Clin. Nutr., 2008, 17, 131-134.

41. Skałecki P., Florek M., Staszowska A., Kaliniak A., Use value and quality of fillets of carp fish (Cyprinidae) reared in polyculture. Żywność. Nauka. Technologia. Jakość, 2015, 1, 75-88 (in Polish, English abstract).

42. Staszowska A., Florek M., Skałecki P., Kaliniak A., Basic chemical composition and content of macro- and microelements in the meat of rainbow trout (Oncorhynchus mykiss) before and after smoking. Episteme Czasopismo Naukowo-Kulturalne, 2013, 21, 215-223 (in Polish, English abstract).

43. Steffens W., Effects of variation in essential fatty acids in fish feeds on nutritive value of freshwater fish for humans. Aquaculture, 1997, 151, 97-119. 
44. Steffens W., Wirth M., Influence of nutrition on the lipid quality of pond fish: common carp (Cyprinus carpio) and tench (Tinca tinca). Aquaculture Int., 2007, 15, 313-319.

45. Szathmári L., Molnár E., Investigation of dry matter and fat content in carp species smoked by hot and cold methods. Aquacult. Int., 2007, 15, 331-336.

46. Testi S., Bonaldo A., Gatta P.P., Badiani A., Nutritional traits of dorsal and ventral fillets from three farmed fish species. Food Chem., 2006, 98, 104-111.

47. Tkaczewska J., Migdał W., Comparison of slaughter yield, contents of basic nutrients, and heavy metals levels in muscles of carp (Cyprinus carpio L.) farmed in various regions in Poland. Żywność. Nauka. Technologia. Jakość, 2012, 6, 180-189 (in Polish, English abstract).

48. Tokur B., Ozkütük S., Atici E., Ozyurt G., Ozyurt C.E., Chemical and sensory quality changes of fish fingers, made from mirror carp (Cyprinus carpio L., 1758), during frozen storage $\left(-18^{\circ} \mathrm{C}\right)$. Food Chem., 2006, 99, 335-341.

49. Trbović D., Marković Z., Petronijević R., Milijašević M., Spirić D., Vranić D., Spirić A., Changes in the proximate and fatty acid composition in carp meat during the semi intensive farming. Tehnologija mesa, 2013, 54, 39-47.

50. Turchini G.M., Mentasti T., Froyland L., Orban E., Caprino F., Moretti V.M., Valfre F., Effects of alternative dietary lipid sources on performance, tissue chemical composition, mitochondrial fatty acid oxidation capabilities and sensory characteristics in brown trout (Salmo trutta L.). Aquaculture, 2003, 225, 251-267.

51. Ulbricht T.L.V., Southgate D.A.T., Coronary heart disease: Seven dietary factors. Lancet, 1991, 338, 985-991.

52. Vasiliadou S., Ambrosiadis I., Vareltzis K., Fletouris D., Gavriilidou I., Effect of smoking on quality parameters of farmed gilthead sea bream (Sparus aurata L.) and sensory attributes of the smoked product. Eur. Food Res. Technol., 2005, 221, 232-236

53. Weichselbaum E., Coe S., Buttriss J., Stanner S., Fish in the diet: A review. Nutrition Bulletin, 2012, 38, 128-177.

54. Witte V. C., Krause G. F., Bailey M.E., A new extraction method for determining 2-thiobarbituric acid values of pork and beef during storage. J. Food Sci., 1970, 35, 582-585.

55. Yanar Y., Fenercioglu H., The utilization of carp (Cyprinus carpio) flesh as fish ball. Turk. J. Vet. Anim. Sci., 1998, 23, 361-365.

56. Zhu Z., Ruan Z., Li B., Meng M., Zeng Q., Quality loss assessment of crisp grass carp (Ctenopharyngodon idellus $\mathrm{C}$. et V) fillets during ice storage. J. Food Process. Preserv., 2013, 37, 254-261.

Submitted: 23 August 2015. Revised: 29 November 2015. Accepted: 30 December 2016. Published on-line: 13 June 2016. 
